\title{
Reflections on the KDIGO Definition of Acute Kidney Injury and Its Integration in the Concept of Acute Diseases and Disorders and Chronic Kidney Diseases
}

\author{
Norbert Lameire
}

Citation: Lameire, N. Reflections on the KDIGO Definition of Acute Kidney Injury and Its Integration in the Concept of Acute Diseases and Disorders and Chronic Kidney Diseases. Kidney Dial. 2022, 2, 68-79. https://doi.org/10.3390/ kidneydial2010008

Academic Editor: Vladimir Tesar

Received: 17 January 2022

Accepted: 9 February 2022

Published: 11 February 2022

Publisher's Note: MDPI stays neutral with regard to jurisdictional claims in published maps and institutional affiliations.

Copyright: (C) 2022 by the author. Licensee MDPI, Basel, Switzerland. This article is an open access article distributed under the terms and conditions of the Creative Commons Attribution (CC BY) license (https:// creativecommons.org/licenses/by/ $4.0 /)$.
Department of Medicine, Ghent University Hospital, 9000 Ghent, Belgium; lameire.norbert@outlook.com

\begin{abstract}
Acute kidney injury (AKI) describes a heterogeneous group of conditions, without specification of their etiology and diagnosed only by indirect markers of glomerular filtration rate (GFR), such as serum creatinine and urine output. Bedside estimation of GFR and detection of structural alterations with novel biomarkers, and stress tests have more recently been developed. These novel findings should probably be included in future AKI definitions. Chronic kidney disease (CKD) is defined by abnormalities in kidney function and structure that persist over $>3$ months and is classified according to cause, GFR, and albuminuria. Acute kidney disease (AKD) is the term representing patients with abnormalities of function and structure with a duration of $\leq 3$ months that fall outside the definitions of AKI or CKD. Since AKI is by definition also AKD, 2 types of AKD have been proposed, one with and one without AKI. AKD without AKI is common, often undetected, occurs frequently in the outpatient population and shows increased risk of CKD, ESKD and mortality. Alternatively, $\mathrm{AKD}$ has also been defined as the period of incomplete recovery following an AKI episode, the latter limited for the duration of 7 days. This contribution discusses the pros and cons of the existence of these 2 definitions of AKD.
\end{abstract}

Keywords: acute kidney disease; acute kidney injury; chronic kidney disease; nomenclature; adherence to guidelines

"By three methods we may learn wisdom: First, by reflection, which is noblest; Second, by imitation, which is easiest; and third by experience, which is the bitterest." —_Confucius (551 BC to 479 BC)

\section{Introduction}

The KDIGO Acute Kidney Injury (AKI) guidelines [1] were published in early 2012 and are based on evidence gathered until mid-2011. This resulted in "consensus" opinions with only $22(25 \%)$ "strong "recommendations, reflecting the paucity of high-level data guiding the management of AKI at that time.

New evidence has become available over the last decade, and an update of the AKI guidelines seems appropriate.

The definitions of AKI, Acute Kidney Disease (AKD) as formulated in the 2012 AKI guidelines [1] and Chronic Kidney Disease (CKD) [2] are tabulated in Table 1.

Kidney Diseases (KDs) are defined by markers of kidney damage (structural criteria) and/or decreased (estimated) glomerular filtration rate (GFR) (functional criteria) persisting for $\leq 3$ months (AKD) or $\geq 3$ months (CKD). AKI is a subset of AKD, and the criteria for defining AKD must include criteria for AKI as well as for CKD.

A recent KDIGO Controversies Conference [3] suggested that the concept of AKD, and the relationships between $\mathrm{AKD}, \mathrm{AKI}$, and CKD should be clarified. A recent Consensus Conference [4] harmonized the definitions and classifications of AKD and CKD, but some issues remained unresolved, particularly the relationship between AKD and AKI.

Figure 1 illustrates a timeline of the most important contributions on the evolution of the definition and classification of AKI [1,4-11]. 
Table 1. Modified from the 2012 KDIGO AKI guideline [1] summarizes the definitions of AKI, AKD, CKD and NKD (non-kidney diseases).

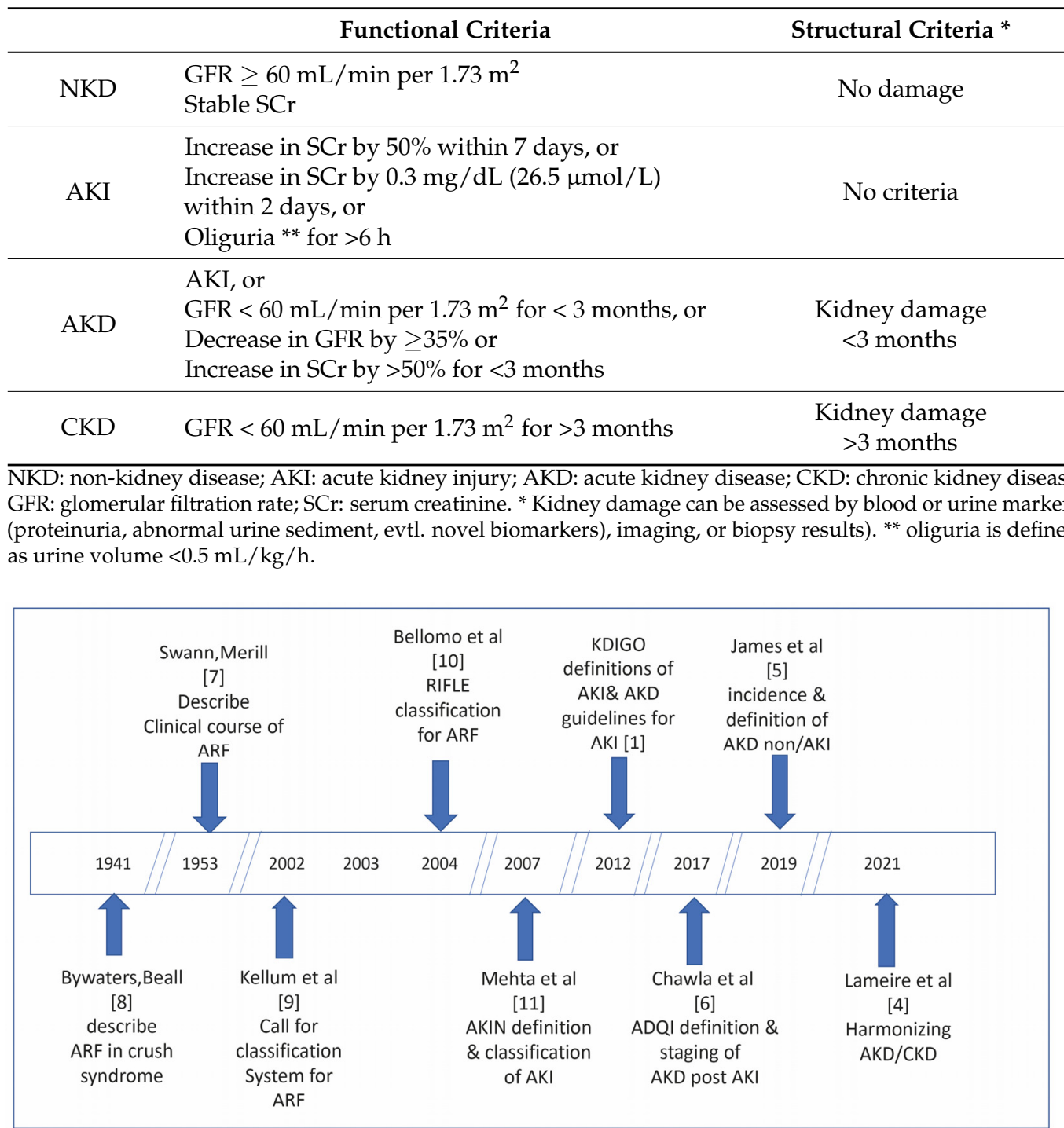

Figure 1. Timeline of the most important contributions on the evolution of the definition and classification of AKI.

\section{Acute Kidney Injury}

AKI is the generic term for a heterogeneous group of conditions characterized by an abrupt and sustained decrease in GFR, occurring over $\leq 7$ days and is diagnosed by an increase in serum creatinine (SCr) or with a decrease in $6 \mathrm{~h}$ urinary output (UO), as shown in the table [1]. The equal importance of both small SCr increases and decreases in UO should be acknowledged. Particularly in ICU patients, intensive monitoring of UO leads to improved detection of AKI and reduced mortality in AKI patients, as well as to lower risk of fluid overload [12-14].

In case of an increased SCr level on admission, AKI can also be defined as a 1.5-fold decreased SCr of a nadir over 7 days within 3 months [5]. AKI is classified by stages according to severity which influence prognosis and management [1]. The 2012 KDIGO definition does not mention the cause or duration of AKI, the criteria for recovery, or the presence of markers of kidney damage [4].

The 2012 AKI consensus definition is based on many studies linking small absolute increases of SCr to poor prognosis, including mortality, length of hospitalization, development of CKD, and heart failure, and hypertension [15-20]. However, associations between 
AKI and, for example hospital mortality, are not necessarily all causal [21] and many retrospective studies do not completely eliminate the role of residual confounding for many of the AKI risk factors [22].

A recent e-alert for an AKI intervention study based on SCr levels found, as expected, an increased diagnosis, a reduced length of stay, and overall improvements in the quality of care, but no change in the 30-day AKI mortality rate [23]. Ikizker et al. [24] recently found that the association with death in AKI patients was markedly attenuated and no longer significant after accounting for degree of renal recovery and proteinuria status at 3 months post-discharge.

The severity and duration of AKI are both important determinants of attributable mortality of AKI. A recent Chinese propensity-matched analysis showed an overall substantial 8.1\% AKI attributable 30-day mortality, except for stage 1 AKI or AKI $<48 \mathrm{~h}$ duration (transient AKI) [25].

There are many limitations related to the KDIGO criteria of AKI diagnosis [26]. Many studies do not measure UO and do not include it in the definition. The addition of UO increases the incidence of AKI and changes the prognostic implications of its identification and staging [13,27-30]. The limitations of the SCr criteria include its delayed increase after an abrupt fall of GFR, especially in fluid overloaded patients and in critical illness with a lowered generation rate of creatinine [26,31-33]. Likewise, SCr does not immediately decrease despite improvement of GFR [34].

As baseline $\mathrm{SCr}$ is the mean outpatient SCr level, measured within a year of hospitalization, preferred above the admission level because it reflects better a steady state of kidney function, not altered by acute illness or progressing AKI [35,36].

\section{Alternative Estimates of GFR}

Serial short $(4 \mathrm{~h})$ creatinine clearances provide more accurate information on kidney function compared to serial SCr measurements in critically ill, unstable patients [37].

Kinetic estimated GFR can be calculated to assess the trajectory of kidney function when SCr values are fluctuating $[34,38]$. Despite some inherent limitations, this method provides a more timely diagnosis, better appreciation of the severity of AKI, and detects renal recovery earlier (recovery of GFR while SCr is still increasing) [39-43]. Although a decrease in GFR is presently not included in the KDIGO AKI definition, this easy and cheap tool could become part of a future AKI definition [43].

A recently developed point-of-care fluorescence-based measured GFR [44] proved to be safe, and accurately measured GFR across a wide range of kidney functions [45]. It could become a bedside tool for risk stratification, early diagnosis, prognosis and therapy guidance, particularly for drug dosing in AKI [46].

Cystatin $C$ is less reliant on muscle mass and dietary intake and offers an alternative approach to estimate GFR [47]. Combination of SCr and cystatin C provided better risk prediction in AKI than either biomarker alone [48,49].

Plasma levels of proenkephalin (PENKid) correlate with GFR and are more sensitive than $\mathrm{SCr}$ to detect AKI in critically ill patients [50,51].

Recent studies suggest that an elevated circulating plasma level of soluble plasminogen activator receptor (suPAR) is a broadly applicable marker for the development of AKI $[52,53]$.

\section{Renal Stress Tests}

\subsection{Renal Functional Reserve (RFR)}

The concept of RFR refers to the ability of the normal kidney to increase the GFR in response to a short-term oral or intravenous administration of a high protein load. An insult that compromises kidney filtration mildly might lower the RFR without causing a decrease in baseline GFR owing to compensatory hyperfiltration in the intact nephrons. Among patients with identical resting GFR, RFR might discriminate those at higher risk of AKI (lower RFR) from those at lower risk (higher RFR)—for reviews [54,55]. Husain-Syed 
et al. [56] reported a significantly lower preoperative RFR in patients with normal resting GFR who experienced post-cardiac surgery AKI versus controls. A follow-up study at 3 months post-cardiac surgery [57] revealed that, except for three patients who developed CKD, all remaining patients showed a normal eGFR $\left(93.3 \pm 15.1 \mathrm{~mL} / \mathrm{min} / 1.73 \mathrm{~m}^{2}\right)$. In patients with a normal eGFR before, and 3 months after elective cardiac surgery, RFR decreased in patients who had developed peri-operative AKI. In patients without AKI, but with increased urinary cell-cycle arrest (CCA) biomarker levels, 3-month RFR also fell. Conversely, for patients without AKI and with no change in biomarkers, median RFR at 3 months remained preserved.

Loss of RFR indicates loss of functioning nephron mass and predicts not only an increased risk for AKI but also incomplete recovery. Measurement of RFR as parameter for AKI risk is particularly useful when the moment of insult (i.e., major surgery) is known. On the other hand, measuring loss or reduction of RFR, in addition to kidney function per se, might be a precise indicator of the degree of post AKI recovery [58].

\subsection{Furosemide Stress Test}

The pharmacology of furosemide allows the prediction of renal tubular integrity given that furosemide is not filtered and that its action is completely dependent on tubular function. In this context, furosemide-induced urine output has been introduced as a safe and well-tolerated stress test and marker of AKI severity in critically ill AKI patients [59]. After a one-time dose of intravenous furosemide to patients with early stage 1 or $2 \mathrm{AKI}$, $(1.0 \mathrm{mg} / \mathrm{kg}$ for loop diuretic naïve patients and $1.5 \mathrm{mg} / \mathrm{kg}$ for those with loop diuretic exposure) a urinary response of $<200 \mathrm{~mL}$ over the first $2 \mathrm{~h}$ post furosemide predicts the progression to AKI Stage 3, including need for RRT.

A number of follow-up applications have shown that this test identifies AKI subjects at higher risk of AKI progression and need for RRT and predicts cessation of continuous RRT in patients with established AKI [60].

\section{Novel Biomarkers and Their Possible Impact on Definition and Classification of AKI}

Biomarkers, potentially reflecting structural kidney damage have been introduced over the last 10 to 15 years. Their clinical application could possibly help in differentiating several phenotypes of AKI based on etiology, prognosis, and molecular pathways, which potentially may require different therapies [32]. Excellent reviews summarizing an impressive number of studies covering several aspects of the usefulness and limitations of these biomarkers are available for the interested reader [61-66]. Some biomarkers such as neutrophil gelatinaseassociated lipocalin (NGAL), and the cell-cycle biomarkers [metalloproteinase inhibitor 2] $\times$ [insulin-like growth factor-binding protein 7] $([$ TIMP-2] $\times$ [IGFBP7]), have been approved by regulatory authorities in some countries.

Dickoppf 3 (DKK3) is a recent promising urinary biomarker in the field of AKI [67] and reflects ongoing tubular injury. High urinary DKK3 levels signify increased risk for (post-cardiac surgery) AKI and further loss of kidney function after an AKI episode [68,69].

Different biomarkers have different windows of opportunity, which makes the optimal timing of their analysis after renal injury difficult, especially when the exact moment of the renal insult is unknown.

Some biomarkers are influenced by chronic comorbidities and acute severity of illness, independent of AKI, and can, thus, be false-positive [70]. It remains currently unknown whether an increase in biomarkers levels without concomitant functional abnormalities is clinically relevant, except maybe as "stress" signals, and whether their measurement will improve patient outcome. Moreover, their high costs must be considered before their introduction in routine surveillance protocols can be recommended.

The 23rd Acute Disease Quality Initiative (ADQI) expert group [61] proposes that clinical information enriched by damage and functional biomarkers could lead to more sensitive AKI definitions and suggests a further subdivision of KDIGO stage 1 AKI into 
3 substages (i.e., 1S, 1A, and 1B) and subcategorizes stages 2 and 3 AKI, depending the presence or absence of elevated biomarkers.

Before these novel biomarkers are included in the definition and classification in a future AKI guideline, as was recently suggested [61], I believe that a critical analysis of all published biomarker results by experts in biomedical evidence is required. However, when further evidence becomes established, structural alterations and criteria for resolution of AKI demonstrated by biomarkers may be important arguments for their inclusion in the AKI definition.

AKI is a clinical syndrome with multiple potential causes and determining its cause is a key element of clinical management [71,72]. The recent KDIGO Nomenclature Conference [73] has correctly suggested adding the cause and not the staging alone to the AKI definition.

The term "injury" has been criticized because patients may suffer from an abrupt decline in GFR, without demonstrable structural kidney injury. Successfully decongested heart failure patients [74-76], treatment with ACEIs or ARBs [77] or with sodium-glucose cotransporter-2 (SGLT2) inhibitors [78], and adequate treatment of hypertension [79] are frequently followed by an acute increase in $\mathrm{SCr}$, but also by lower long-term mortality and/or improvement of the underlying disease. In these scenarios, the term "injury" may not be appropriate. The 2012 KDIGO guideline anticipated this difficulty and introduced the acronym AKI that, besides "injury" also means "impairment" [1]. It must however be recognized that the acronym "impairment" has rarely been used.

The opposite situation where increased urinary biomarker levels, potentially reflecting damage occur in the absence of a rise in SCr, has been called 'acute subclinical injury' $[80,81]$. Many clinical cases of "subclinical" AKI are the consequence of the delayed rise in SCr where a decline of GFR is not yet measured [82], explaining why such 'subclinical AKI' has a similar prognosis as 'true' AKI [83].

Despite all the limitations and caveats described above, the consensus KDIGO definition and staging of AKI were favorably accepted and have enhanced communication, improved recognition and awareness of kidney disease, and facilitated the comparison of outcomes between AKI studies and interventions [84-86].

Were the KDIGO AKI definitions and management recommendations as suggested in the AKI guidelines universally applied, and has this resulted in improved outcomes? [87].

In a total of $127 \mathrm{AKI}$ studies, the KDIGO definition was inconsistently applied, and the methods for application were poorly described [88]. Only 49 studies (28.2\%) used a change in UO, and only $135(77.4 \%)$ used a $0.3 \mathrm{mg} / \mathrm{dL}$ SCr rise in $48 \mathrm{~h}$. There was no consensus for defining AKI and describing its sequelae among the experts who participated in a Delphi process. These sobering results could probably explain the rather low adherence to the most evident therapeutic recommendations as formulated in the 2012 KDIGO AKI guideline [89,90].

Moledina et al. [91] evaluated adherence to and inter-hospital variability in AKI best practices at three university hospitals and noted high variation in $\mathrm{SCr}$ monitoring, urinalysis, maintenance of normoglycemia, mild hyperkalemia, and hypotension. Lack of awareness of the guidelines and the low-quality evidence supporting their recommendations were the most prominent explanations for the low adherence to the guidelines.

A recent systematic review and meta-analysis [92] suggests that implementation of AKI care bundles in hospitalized patients reduces moderate to severe AKI, but that the overall compliance to AKI care bundles is highly variable.

\section{The Concept of AKD and Its Interrelationship with AKI and CKD}

The 2012 KDIGO AKI guideline group realized that, in practice, some patients present with acute (i.e., $\leq 3$ months) alterations of kidney function and structure that do not meet the criteria for the definition of either AKI or CKD. For this group of patients, the operational definition of acute kidney disease (AKD) was proposed. It should be understood that AKD also encompasses AKI. [1] (Table 1). 
Concerns about this concept of AKD that were expressed by several other guideline organizations $[85,86]$ were summarized by Barry and James [93]. The European ERBP guideline group did not comment on the AKD concept [84].

AKD is diagnosed when, compared to SCr measurements at least 3 months prior, a new or previously unrecognized increase in $\mathrm{SCr}$ is present. AKD patients show either abnormalities in kidney structure or function that are less severe than in AKI or that do not develop as rapidly as in AKI. They may suffer from the same diseases that cause AKI or CKD, and which could be detected, evaluated, and treated before they evolve to AKI or CKD.

Recent data suggest that AKD not associated with AKI is common, is often undetected, occurs more frequently in the outpatient population and has an overall increased risk of incident and progressive CKD, ESKD and mortality [5].

Although the definition of AKD without AKI is still rarely used, there is no doubt that it is common and harmful, and that the existing KDIGO definition for AKD can be accepted [4,94].

In 2017, the Acute Dialysis Quality Initiative (ADQI) 16 report proposed an alternative definition and classification of AKD [6]. The report conceived of AKI as preceding AKD in most cases; proposed a limitation for the duration of AKI as 7 days, with persistence beyond this time as AKD and suggested a classification of AKD according to the preceding AKI stage [6]. ADQI defines thus AKD as the period of incomplete recovery of kidney function in survivors of AKI beyond 7 days. Patients suffering AKI and dying within 7 days or showing an early and sustained renal recovery within 7 days are labeled as "true" AKI patients.

Interestingly, a comparison of the primary composite outcomes of incident CKD, kidney failure, or death between hospitalized patients with AKD without AKI and patients with AKD post-AKI, the latter defined by the ADQI definition, was recently published [95]. Compared with no AKD, both groups with AKD showed similar hazard ratios for the primary outcomes. A number of studies, mostly in ICU patients with AKI, used the ADQI definition [4]. Not surprisingly, these studies confirm the well-known increased risks of both mortality and incident CKD associated with this "incompletely" recovered AKI.

The Consensus Workgroup [4] believed that an arbitrary time-based definition for the duration of AKI of 7 days, as proposed by the ADQI group [6], "warrants additional consideration", and deferred the development of specific criteria for duration and resolution of AKI to the next AKI guideline updating group. Until then, some ambiguity will remain about the appropriate nomenclature for patients following an episode of AKI.

A number of difficulties remain when two entities of AKD, one with and another without AKI, are considered.

First, the introduction of two different types of AKDs is prone to create confusion in daily non-nephrology practice. Most patients with AKD without AKI reside in the community while the majority of those suffering AKI is hospitalized leading to groups of "AKD" patients with different prognostic outcomes.

Second, most clinicians may find it difficult to change the definition AKI into AKD after 7 days, when confronted with patients who need dialysis beyond 1 week, or even up to 3 months after the start of AKI [96-98].

Third, despite being based on theoretical and logical concepts [54], the staging of post $\mathrm{AKI} / \mathrm{AKD}$ proposed by the ADQI group is complex and not very user-friendly. For example, the staging starts from stage 0 , reflecting "subacute" AKD, the latter further subdivided in grades $\mathrm{A}, \mathrm{B}$, and $\mathrm{C}$, depending on the absence or presence of elevated biomarkers [6].

Waiting for the results of future deliberations, I suggest to apply the 2012 KDIGO AKI guideline where the period up to 3 months after diagnosis of AKI, would be called "post-AKI", reminding however that AKI trajectories and duration of AKI define different patient groups and impact outcomes, both in children [99] as well as in adults [100-103]. An accurate definition of post-AKI recovery is not yet available. Five distinct recovery phe- 
notypes following AKI were identified based on the clinical course of critically ill patients in the first week after AKI manifestation [104]. The outcomes of these recovery phenotypes were quite different. Extensive reviews on renal recovery are available [6,105-109].

The main concern in the field of nephrology for the non-nephrologist is the care given to the AKD patient in the community and to those discharged from the hospital after an episode of AKI. It is at present well known that the survival of episodes of relatively mild AKI lasting more than 3-4 days is associated with an increased risk of both short- and long-term mortality, cardiovascular diseases, and hypertension. These patients are also at considerable risk for developing de novo CKD, progression of pre-existing CKD, and evolution towards end stage kidney disease (for review [110]). The short-term prognosis of a post AKI discharged patient depends largely on the severity of the AKI, which is also determined by the underlying acute or chronic diseases that were the cause of or associated with the AKI episode [111,112].

It is clear that nephrological follow-up of the post-AKI patient by the nephrologist alone will not be sufficient and that adequate communication with the referring physicians responsible for this immediate follow-up and treatment of the ongoing illness is absolutely mandatory. Some of the practical proposals for post-AKI care are summarized in [113]; the management of the non-AKI AKD patient is provided in the recent Consensus Report on AKD [4].

\section{Conclusions and Future Perspectives}

This contribution discusses several points, which may be relevant for future updates of the definition of AKI and its integration in the concepts of AKD and CKD.

The definition of AKI should be expanded by adding its etiology, by describing the different phenotypes of AKI, possibly based on functional alterations and markers of structural damage, and on recovery patterns after AKI. A more precise definition of "recovery" after an episode of AKI should be developed.

More accurate markers of kidney function in AKI, beyond SCr and urine output, i.e., instantaneous bedside measurement of changes in GFR, should be further investigated. Attention to adequate follow-up of the post-AKI patient outside the nephrology community is absolutely necessary.

Applying the terminology of AKD to a period between day 7 and 3 months post AKI may be theoretically sound, but is confusing and draws the attention away from the more frequent, often "subclinical", episodes of "real" AKD in the community that are major drivers of the progression to CKD and end stage kidney disease with their associated morbidity and mortality.

Funding: This research received no external funding.

Institutional Review Board Statement: Not applicable.

Informed Consent Statement: Not applicable.

Data Availability Statement: Not applicable.

Conflicts of Interest: The author declares no conflict of interest.

\section{References}

1. Kidney Diseases: Improving global Outcomes (KDIGO). Acute Kidney Injury work Group. Kidney Disease Improviing Global Outcomes Clinical Practice Guideline for Acute Kidney Injury. Kidney Int. Suppl. 2012, 2, 1-138. Available online: https:/ / kdigo.org/wp-content/uploads/2016/10/KDIGO-2012-AKI-Guideline-English.pdf (accessed on 12 December 2021).

2. Kidney Diseases: Improving global Outcomes (KDIGO). The 2012 Clinical Practice Guideline for the Evaluation and Management of Chronic Kidney Disease (CKD). Kidney Int. Suppl. 2013, 3, 1-150. Available online: https://www.sciencedirect.com/journal/ kidney-international-supplements/vol/3/issue/1 (accessed on 12 December 2021).

3. Ostermann, M.; Bellomo, R.; Burdmann, E.A.; Doi, K.; Endre, Z.H.; Goldstein, S.L.; Kane-Gill, S.L.; Liu, K.D.; Prowle, J.R.; Shaw, A.D.; et al. Controversies in acute kidney injury: Conclusions from a Kidney Disease: Improving Global Outcomes (KDIGO) Conference. Kidney Int. 2020, 98, 294-309. [CrossRef] [PubMed] 
4. Lameire, N.H.; Levin, A.; Kellum, J.A.; Cheung, M.; Jadoul, M.; Winkelmayer, W.C.; Stevens, P.E. Harmonizing acute and chronic kidney disease definition and classifi cati on: Report of a Kidney Disease: Improving Global Outcomes (KDIGO) Consensus Conference. Kidney Int. 2021, 100, 516-526. [CrossRef]

5. James, M.T.; Levey, A.S.; Tonelli, M.; Tan, Z.; Barry, R.; Pannu, N.; Ravani, P.; Klarenbach, S.W.; Manns, B.J.; Hemmelgarn, B.R. Incidence and Prognosis of Acute Kidney Diseases and Disorders Using an Integrated Approach to Laboratory Measurements in a Universal Health Care System. JAMA Netw. Open 2019, 2, e191795. [CrossRef]

6. Chawla, L.S.; Bellomo, R.; Bihorac, A.; Goldstein, S.L.; Siew, E.D.; Bagshaw, S.M.; Bittleman, D.; Cruz, D.; Endre, Z.; Fitzgerald, R.L.; et al. Acute kidney disease and renal recovery: Consensus report of the Acute Disease Quality Initiative (ADQI) 16 Workgroup. Nat. Rev. Nephrol. 2017, 13, 241-257. [CrossRef]

7. Swann, R.C.; Merrill, J.P. The clinical course of acute renal failure. Medicine 1953, 32, 215-292. [CrossRef]

8. Bywaters, E.G.; Beal, L.D. Crush Injuries with Impairment of Renal Function. Br. Med. J. 1941, 1, 427-432. [CrossRef]

9. Kellum, J.A.; Levin, N.; Bouman, C.; Lameire, N. Developing a consensus classification system for acute renal failure. Curr. Opin. Crit. Care. 2002, 8, 509-514. [CrossRef]

10. Bellomo, R.; Ronco, C.; Kellum, J.A.; Mehta, R.L.; Palevsky, P. Acute renal failure-definition, outcome measures, animal models, fluid therapy and information technology needs: The Second International Consensus Conference of the Acute Dialysis Quality Initiative (ADQI) Group. Crit. Care. 2004, 8, R204-R212. [CrossRef]

11. Mehta, R.L.; Kellum, J.A.; Shah, S.V.; Molitoris, B.A.; Ronco, C.; Warnock, D.G.; Levin, A.; The Acute Kidney Injury Network. Acute Kidney Injury Network: Report of an initiative to improve outcomes in acute kidney injury. Crit. Care 2007, 11, R31. [CrossRef] [PubMed]

12. Jin, K.; Murugan, R.; Sileanu, F.E.; Foldes, E.; Priyanka, P.; Clermont, G.; Kellum, J.A. Intensive Monitoring of Urine Output Is Associated With Increased Detection of Acute Kidney Injury and Improved Outcomes. Chest 2017, 152, 972-979. [CrossRef] [PubMed]

13. Vanmassenhove, J.; Steen, J.; Vansteelandt, S.; Morzywolek, P.; Hoste, E.; Decruyenaere, J.; Benoit, D.; Van Biesen, W. The importance of the urinary output criterion for the detection and prognostic meaning of AKI. Sci. Rep. 2021, 11, 11089. [CrossRef] [PubMed]

14. Minor, J.; Smith, A.; Deutsch, F.; Kellum, J.A. Automated versus manual urine output monitoring in the intensive care unit. Sci. Rep. 2021, 11, 17429. [CrossRef] [PubMed]

15. Lassnigg, A.; Schmidlin, D.; Mouhieddine, M.; Bachmann, L.M.; Druml, W.; Bauer, P.; Hiesmayr, M. Minimal changes of serum creatinine predict prognosis in patients after cardiothoracic surgery: A prospective cohort study. J. Am. Soc. Nephrol. 2004, 15, 1597-1605. [CrossRef]

16. Chertow, G.M.; Burdick, E.; Honour, M.; Bonventre, J.V.; Bates, D.W. Acute kidney injury, mortality, length of stay, and costs in hospitalized patients. J. Am. Soc. Nephrol. 2005, 16, 3365-3370. [CrossRef]

17. Chawla, L.S.; Kimmel, P.L. Acute kidney injury and chronic kidney disease: An integrated clinical syndrome. Kidney Int. 2012, 82, 516-524. [CrossRef]

18. Rodríguez, E.; Arias-Cabrales, C.; Bermejo, S.; Sierra, A.; Burballa, C.; Soler, M.J.; Barrios, C.; Pascual, J. Impact of Recurrent Acute Kidney Injury on Patient Outcomes. Kidney Blood Press Res. 2018, 43, 34-44. [CrossRef]

19. Horne, K.L.; Packington, R.; Monaghan, J.; Reilly, T.; Selby, N.M. Three-year outcomes after acute kidney injury: Results of a prospective parallel group cohort study. BMJ Open 2017, 7, e015316. [CrossRef]

20. Go, A.S.; Hsu, C.Y.; Yang, J.; Tan, T.C.; Zheng, S.; Ordonez, J.D.; Liu, K.D. Acute Kidney Injury and Risk of Heart Failure and Atherosclerotic Events. Clin. J. Am. Soc. Nephrol. 2018, 13, 833-841. [CrossRef]

21. Selby, N.M.; Kolhe, N.V.; McIntyre, C.W.; Monaghan, J.; Lawson, N.; Elliott, D.; Packington, R.; Fluck, R.J. Defining the cause of death in hospitalised patients with acute kidney injury. PLOS ONE 2012, 7, e48580. [CrossRef] [PubMed]

22. Coca, S. Acute Kidney Injury: "Trials and Tribulations". NephSAP 2019, 18, 49-53.

23. Selby, N.M.; Casula, A.; Lamming, L.; Stoves, J.; Samarasinghe, Y.; Lewington, A.J.; Roberts, R.; Shah, N.; Johnson, M.; Jackson, N.; et al. An Organizational-Level Program of Intervention for AKI: A Pragmatic Stepped Wedge Cluster Randomized Trial. J. Am. Soc. Nephrol. 2019, 30, 505-515. [CrossRef] [PubMed]

24. Ikizler, T.A.; Parikh, C.R.; Himmelfarb, J.; Chinchilli, V.M.; Liu, K.D.; Coca, S.G.; Garg, A.X.; Hsu, C.Y.; Siew, E.D.; Wurfel, M.M.; et al. A prospective cohort study of acute kidney injury and kidney outcomes, cardiovascular events, and death. Kidney Int. 2021, 99, 456-465. [CrossRef] [PubMed]

25. Jiang, Y.J.; Xi, X.M.; Jia, H.M.; Zheng, X.; Wang, M.P.; Li, W.X. The attributable mortality of new-onset acute kidney injury among critically ill patients: A propensity-matched analysis based on a multicentre prospective cohort study. Int. Urol. Nephrol. 2022 [CrossRef]

26. Thomas, M.E.; Blaine, C.; Dawnay, A.; Devonald, M.A.; Ftouh, S.; Laing, C.; Latchem, S.; Lewington, A.; Milford, D.V.; Ostermann, $\mathrm{M}$. The definition of acute kidney injury and its use in practice. Kidney Int. 2015, 87, 62-73. [CrossRef]

27. Kellum, J.A.; Sileanu, F.E.; Murugan, R.; Lucko, N.; Shaw, A.D.; Clermont, G. Classifying AKI by Urine Output versus Serum Creatinine Level. J. Am. Soc. Nephrol. 2015, 26, 2231-2238. [CrossRef]

28. Quan, S.; Pannu, N.; Wilson, T.; Ball, C.; Tan, Z.; Tonelli, M.; Hemmelgarn, B.R.; Dixon, E.; James, M.T. Prognostic implications of adding urine output to serum creatinine measurements for staging of acute kidney injury after major surgery: A cohort study. Nephrol. Dial. Transplant. 2016, 31, 2049-2056. [CrossRef] 
29. Koeze, J.; Keus, F.; Dieperink, W.; van der Horst, I.C.; Zijlstra, J.G.; van Meurs, M. Incidence, timing and outcome of AKI in critically ill patients varies with the definition used and the addition of urine output criteria. BMC Nephrol. 2017, 18, 70. [CrossRef]

30. Wiersema, R.; Jukarainen, S.; Eck, R.J.; Kaufmann, T.; Koeze, J.; Keus, F.; Pettilä, V.; van der Horst, I.C.C.; Vaara, S.T. Different applications of the KDIGO criteria for AKI lead to different incidences in critically ill patients: A post hoc analysis from the prospective observational SICS-II study. Crit. Care 2020, 24, 164. [CrossRef]

31. Waikar, S.S.; Bonventre, J.V. Creatinine kinetics and the definition of acute kidney injury. J. Am. Soc. Nephrol. 2009, 20, 672-679. [CrossRef] [PubMed]

32. Moledina, D.G.; Parikh, C.R. Phenotyping of Acute Kidney Injury: Beyond Serum Creatinine. Semin. Nephrol. $2018,38,3-11$. [CrossRef] [PubMed]

33. Kashani, K.; Rosner, M.H.; Ostermann, M. Creatinine: From physiology to clinical application. Eur. J. Intern. Med. 2020, 72, 9-14. [CrossRef] [PubMed]

34. Chen, S. Retooling the creatinine clearance equation to estimate kinetic GFR when the plasma creatinine is changing acutely. J. Am. Soc. Nephrol. 2013, 24, 877-888. [CrossRef] [PubMed]

35. Liu, K.D.; Hsu, C.Y.; Yang, J.; Tan, T.C.; Zheng, S.; Ordonez, J.D.; Go, A.S. Acute Kidney Injury Ascertainment Is Affected by the Use of First Inpatient Versus Outpatient Baseline Serum Creatinine. Kidney Int. Rep. 2018, 3, 211-215. [CrossRef] [PubMed]

36. Siew, E.D.; Ikizler, T.A.; Matheny, M.E.; Shi, Y.; Schildcrout, J.S.; Danciu, I.; Dwyer, J.P.; Srichai, M.; Hung, A.M.; Smith, J.P.; et al. Estimating baseline kidney function in hospitalized p.p.patients with impaired kidney function. Clin. J. Am. Soc. Nephrol. 2012, 7, 712-719. [CrossRef] [PubMed]

37. Pickering, J.W.; Frampton, C.M.; Walker, R.J.; Shaw, G.M.; Endre, Z.H. Four hour creatinine clearance is better than plasma creatinine for monitoring renal function in critically ill patients. Crit. Care 2012, 16, R107. [CrossRef]

38. Chen, S. Kinetic Glomerular Filtration Rate in Routine Clinical Practice-Applications and Possibilities. Adv. Chronic Kidney Dis. 2018, 25, 105-114. [CrossRef]

39. Dewitte, A.; Joannès-Boyau, O.; Sidobre, C.; Fleureau, C.; Bats, M.L.; Derache, P.; Leuillet, S.; Ripoche, J.; Combe, C.; Ouattara, A. Kinetic eGFR and Novel AKI Biomarkers to Predict Renal Recovery. Clin. J. Am. Soc. Nephrol. 2015, 10, 1900-1910. [CrossRef]

40. Pianta, T.J.; Endre, Z.H.; Pickering, J.W.; Buckley, N.A.; Peake, P.W. Kinetic Estimation of GFR Improves Prediction of Dialysis and Recovery after Kidney Transplantation. PLOS ONE 2015, 10, e0125669. [CrossRef]

41. Seelhammer, T.G.; Maile, M.D.; Heung, M.; Haft, J.W.; Jewell, E.S.; Engoren, M. Kinetic estimated glomerular filtration rate and acute kidney injury in cardiac surgery patients. J. Crit. Care 2016, 31, 249-254. [CrossRef] [PubMed]

42. O'Sullivan, E.D.; Doyle, A. The clinical utility of kinetic glomerular filtration rate. Clin. Kidney J. 2017, 10, 202-208. [CrossRef] [PubMed]

43. Christiadi, D.; Erlich, J.; Levy, M.; Herath, S.; Qian, J.; Boardman, S.; Campbell, C.; Kotwal, S.; Horvath, A.R.; Endre, Z. The kinetic estimated glomerular filtration rate ratio predicts acute kidney injury. Nephrology 2021, 26, 782-789. [CrossRef]

44. Wang, E.; Meier, D.J.; Sandoval, R.M.; Von Hendy-Willson, V.E.; Pressler, B.M.; Bunch, R.M.; Alloosh, M.; Sturek, M.S.; Schwartz, G.J.; Molitoris, B.A. A portable fiberoptic ratiometric fluorescence analyzer provides rapid point-of-care determination of glomerular filtration rate in large animals. Kidney Int. 2012, 81, 112-117. [CrossRef] [PubMed]

45. Rizk, D.V.; Meier, D.; Sandoval, R.M.; Chacana, T.; Reilly, E.S.; Seegmiller, J.C.; DeNoia, E.; Strickland, J.S.; Muldoon, J.; Molitoris, B.A. A Novel Method for Rapid Bedside Measurement of GFR. J. Am. Soc. Nephrol 2018, 29, 1609-1613. [CrossRef] [PubMed]

46. Schneider, A.G.; Molitoris, B.A. Real-time glomerular filtration rate: Improving sensitivity, accuracy and prognostic value in acute kidney injury. Curr Opin. Crit. Care 2020, 26, 549-555. [CrossRef]

47. Molitoris, B.A.; Reilly, E.S. Quantifying Glomerular Filtration Rates in Acute Kidney Injury: A Requirement for Translational Success. Semin. Nephrol. 2016, 36, 31-41. [CrossRef]

48. Spahillari, A.; Parikh, C.R.; Sint, K.; Koyner, J.L.; Patel, U.D.; Edelstein, C.L.; Passik, C.S.; Thiessen-Philbrook, H.; Swaminathan, M.; Shlipak, M.G. Serum cystatin C- versus creatinine-based definitions of acute kidney injury following cardiac surgery: A prospective cohort study. Am. J. Kidney Dis. 2012, 60, 922-929. [CrossRef]

49. Park, M.; Shlipak, M.G.; Thiessen-Philbrook, H.; Garg, A.X.; Koyner, J.L.; Coca, S.G.; Parikh, C.R. Association of Peak Changes in Plasma Cystatin C and Creatinine With Death After Cardiac Operations. Ann. Thorac. Surg. 2016, 101, 1395-1401. [CrossRef]

50. Beunders, R.; Struck, J.; Wu, A.H.B.; Zarbock, A.; Di Somma, S.; Mehta, R.L.; Koyner, J.L.; Nadim, M.K.; Maisel, A.S.; Murray, P.T.; et al. Proenkephalin (PENK) as a Novel Biomarker for Kidney Function. J. Appl. Lab. Med. 2017, 2, 400-412. [CrossRef]

51. Khorashadi, M.; Beunders, R.; Pickkers, P.; Legrand, M. Proenkephalin: A New Biomarker for Glomerular Filtration Rate and Acute Kidney Injury. Nephron 2020, 144, 655-661. [CrossRef] [PubMed]

52. Hayek, S.S.; Leaf, D.E.; Samman Tahhan, A.; Raad, M.; Sharma, S.; Waikar, S.S.; Sever, S.; Camacho, A.; Wang, X.; Dande, R.R.; et al. Soluble Urokinase Receptor and Acute Kidney Injury. N. Engl. J. Med. 2020, 382, 416-426. [CrossRef] [PubMed]

53. Iversen, E.; Houlind, M.B.; Eugen-Olsen, J. Soluble Urokinase Receptor and Acute Kidney Injury. N. Engl. J. Med. 2020, 382, 2166-2167. [CrossRef] [PubMed]

54. Kellum, J.A.; Ronco, C.; Bellomo, R. Conceptual advances and evolving terminology in acute kidney disease. Nat. Rev. Nephrol. 2021, 17, 493-502. [CrossRef]

55. Fuhrman, D.Y. The Role of Renal Functional Reserve in Predicting Acute Kidney Injury. Crit. Care Clin. 2021, 37, 399-407. [CrossRef] 
56. Husain-Syed, F.; Ferrari, F.; Sharma, A.; Danesi, T.H.; Bezerra, P.; Lopez-Giacoman, S.; Samoni, S.; de Cal, M.; Corradi, V.; Virzì, G.M.; et al. Preoperative Renal Functional Reserve Predicts Risk of Acute Kidney Injury After Cardiac Operation. Ann. Thorac. Surg. 2018, 105, 1094-1101. [CrossRef]

57. Husain-Syed, F.; Ferrari, F.; Sharma, A.; Hinna Danesi, T.; Bezerra, P.; Lopez-Giacoman, S.; Samoni, S.; de Cal, M.; Corradi, V.; Virzì, G.M.; et al. Persistent decrease of renal functional reserve in patients after cardiac surgery-associated acute kidney injury despite clinical recovery. Nephrol. Dial. Transplant. 2019, 34, 308-317. [CrossRef]

58. Sharma, A.; Mucino, M.J.; Ronco, C. Renal functional reserve and renal recovery after acute kidney injury. Nephron. Clin. Pract. 2014, 127, 94-100. [CrossRef]

59. Chawla, L.S.; Davison, D.L.; Brasha-Mitchell, E.; Koyner, J.L.; Arthur, J.M.; Shaw, A.D.; Tumlin, J.A.; Trevino, S.A.; Kimmel, P.L.; Seneff, M.G. Development and standardization of a furosemide stress test to predict the severity of acute kidney injury. Crit. Care 2013, 17, R207. [CrossRef]

60. McMahon, B.A.; Chawla, L.S. The furosemide stress test: Current use and future potential. Ren. Fail. 2021, 43, 830-839. [CrossRef]

61. Ostermann, M.; Zarbock, A.; Goldstein, S.; Kashani, K.; Macedo, E.; Murugan, R.; Bell, M.; Forni, L.; Guzzi, L.; Joannidis, M.; et al. Recommendations on Acute Kidney Injury Biomarkers From the Acute Disease Quality Initiative Consensus Conference: A Consensus Statement. JAMA Netw. Open 2020, 3, e2019209. [CrossRef] [PubMed]

62. Zhang, W.R.; Parikh, C.R. Biomarkers of Acute annd Chronic Kidney Disease. Annu. Rev. Physiol. 2019, 81, 309-333. [CrossRef] [PubMed]

63. Albert, C.; Haase, M.; Albert, A.; Zapf, A.; Braun-Dullaeus, R.C.; Haase-Fielitz, A. Biomarker-Guided Risk Assessment for Acute Kidney Injury: Time for Clinical Implementation? Ann. Lab. Med. 2021, 41, 1-15. [CrossRef] [PubMed]

64. Kellum, J.A.; Artigas, A.; Gunnerson, K.J.; Honore, P.M.; Kampf, J.P.; Kwan, T.; McPherson, P.; Nguyen, H.B.; Rimmelé, T.; Shapiro, N.I.; et al. Use of Biomarkers to Identify Acute Kidney Injury to Help Detect Sepsis in Patients With Infection. Crit Care Med. 2021, 49, e360-e368. [CrossRef] [PubMed]

65. Kulvichit, W.; Kellum, J.A.; Srisawat, N. Biomarkers in Acute Kidney Injury. Crit. Care Clin. 2021, 37, 385-398. [CrossRef] [PubMed]

66. Srisawat, N.; Kellum, J.A. The Role of Biomarkers in Acute Kidney Injury. Crit. Care Clin. 2020, 36, 125-140. [CrossRef]

67. Fang, X.; Hu, J.; Chen, Y.; Shen, W.; Ke, B. Dickkopf-3: Current Knowledge in Kidney Diseases. Front. Physiol. 2020, 11, 533344. [CrossRef] [PubMed]

68. Schunk, S.J.; Zarbock, A.; Meersch, M.; Küllmar, M.; Kellum, J.A.; Schmit, D.; Wagner, M.; Triem, S.; Wagenpfeil, S.; Gröne, H.J.; et al. Association between urinary dickkopf-3, acute kidney injury, and subsequent loss of kidney function in patients undergoing cardiac surgery: An observational cohort study. Lancet 2019, 394, 488-496. [CrossRef]

69. Schunk, S.J.; Speer, T.; Petrakis, I.; Fliser, D. Dickkopf 3-a novel biomarker of the 'kidney injury continuum'. Nephrol. Dial. Transplant. 2021, 36, 761-767. [CrossRef]

70. Bell, M.; Larsson, A.; Venge, P.; Bellomo, R.; Mårtensson, J. Assessment of cell-cycle arrest biomarkers to predict early and delayed acute kidney injury. Dis. Markers 2015, 2015, 158658. [CrossRef]

71. Kellum, J.A.; Lameire, N. The definition of acute kidney injury. Lancet 2018, 391, 202-203. [CrossRef]

72. Selby, N.M. A Comment on the Diagnosis and Definition of Acute Kidney Injury. Nephron 2019, 141, 203-206. [CrossRef] [PubMed]

73. Levey, A.S.; Eckardt, K.U.; Dorman, N.M.; Christiansen, S.L.; Cheung, M.; Jadoul, M.; Winkelmayer, W.C. Nomenclature for kidney function and disease-executive summary and glossary from a Kidney Disease: Improving Global Outcomes (KDIGO) consensus conference. Eur. Heart J. 2020, 41, 4592-4598. [CrossRef] [PubMed]

74. Ahmad, T.; Jackson, K.; Rao, V.S.; Tang, W.H.W.; Brisco-Bacik, M.A.; Chen, H.H.; Felker, G.M.; Hernandez, A.F.; O'Connor, C.M.; Sabbisetti, V.S.; et al. Worsening Renal Function in Patients With Acute Heart Failure Undergoing Aggressive Diuresis Is Not Associated With Tubular Injury. Circulation 2018, 137, 2016-2028. [CrossRef] [PubMed]

75. Brisco, M.A.; Zile, M.R.; Hanberg, J.S.; Wilson, F.P.; Parikh, C.R.; Coca, S.G.; Tang, W.H.; Testani, J.M. Relevance of Changes in Serum Creatinine During a Heart Failure Trial of Decongestive Strategies: Insights From the DOSE Trial. J. Card. Fail. 2016, 22, 753-760. [CrossRef] [PubMed]

76. van der Meer, P.; Postmus, D.; Ponikowski, P.; Cleland, J.G.; O'Connor, C.M.; Cotter, G.; Metra, M.; Davison, B.A.; Givertz, M.M.; Mansoor, G.A.; et al. The predictive value of short-term changes in hemoglobin concentration in patients presenting with acute decompensated heart failure. J. Am. Coll. Cardiol 2013, 61, 1973-1981. [CrossRef]

77. Brar, S.; Ye, F.; James, M.T.; Hemmelgarn, B.; Klarenbach, S.; Pannu, N. Association of Angiotensin-Converting Enzyme Inhibitor or Angiotensin Receptor Blocker Use With Outcomes After Acute Kidney Injury. JAMA Intern. Med. 2018, 178, 1681-1690. [CrossRef]

78. Wanner, C.; Heerspink, H.J.L.; Zinman, B.; Inzucchi, S.E.; Koitka-Weber, A.; Mattheus, M.; Hantel, S.; Woerle, H.J.; Broedl, U.C.; von Eynatten, M.; et al. Empagliflozin and Kidney Function Decline in Patients with Type 2 Diabetes: A Slope Analysis from the EMPA-REG OUTCOME Trial. J. Am. Soc. Nephrol. 2018, 29, 2755-2769. [CrossRef]

79. Rocco, M.V.; Sink, K.M.; Lovato, L.C.; Wolfgram, D.F.; Wiegmann, T.B.; Wall, B.M.; Umanath, K.; Rahbari-Oskoui, F.; Porter, A.C.; Pisoni, R.; et al. Effects of Intensive Blood Pressure Treatment on Acute Kidney Injury Events in the Systolic Blood Pressure Intervention Trial (SPRINT). Am. J. Kidney Dis. 2018, 71, 352-361. [CrossRef] 
80. Haase, M.; Kellum, J.A.; Ronco, C. Subclinical AKI-an emerging syndrome with important consequences. Nat. Rev. Nephrol. 2012, 8, 735-739. [CrossRef]

81. Huen, S.C.; Parikh, C.R. Molecular phenotyping of clinical AKI with novel urinary biomarkers. Am. J. Physiol. Renal. Physiol. 2015, 309, F406-F413. [CrossRef] [PubMed]

82. Vanmassenhove, J.; Van Biesen, W.; Vanholder, R.; Lameire, N. Subclinical AKI: Ready for primetime in clinical practice? J. Nephrol. 2019, 32, 9-16. [CrossRef] [PubMed]

83. Ronco, C.; Kellum, J.A.; Haase, M. Subclinical AKI is still AKI. Crit. Care 2012, 16, 313. [CrossRef] [PubMed]

84. Fliser, D.; Laville, M.; Covic, A.; Fouque, D.; Vanholder, R.; Juillard, L.; Van Biesen, W. A European Renal Best Practice (ERBP) position statement on the Kidney Disease Improving Global Outcomes (KDIGO) clinical practice guidelines on acute kidney injury: Part 1: Definitions, conservative management and contrast-induced nephropathy. Nephrol. Dial. Transplant. 2012, 27, 4263-4272. [CrossRef] [PubMed]

85. Palevsky, P.M.; Liu, K.D.; Brophy, P.D.; Chawla, L.S.; Parikh, C.R.; Thakar, C.V.; Tolwani, A.J.; Waikar, S.S.; Weisbord, S.D. KDOQI US commentary on the 2012 KDIGO clinical practice guideline for acute kidney injury. Am. J Kidney Dis. 2013, 61, 649-672. [CrossRef] [PubMed]

86. James, M.; Bouchard, J.; Ho, J.; Klarenbach, S.; LaFrance, J.P.; Rigatto, C.; Wald, R.; Zappitelli, M.; Pannu, N. Canadian Society of Nephrology commentary on the 2012 KDIGO clinical practice guideline for acute kidney injury. Am. J. Kidney Dis. 2013, 61, 673-685. [CrossRef] [PubMed]

87. Lameire, N.; Vanmassenhove, J.; Lewington, A. Did KDIGO guidelines on acute kidney injury improve patient outcome? Intensive Care Med. 2017, 43, 921-923. [CrossRef]

88. Guthrie, G.; Guthrie, B.; Walker, H.; James, M.T.; Selby, N.M.; Tonelli, M.; Bell, S. Developing an AKI Consensus Definition for Database Research: Findings From a Scoping Review and Expert Opinion Using a Delphi Process. Am. J. Kidney Dis. 2021 Available online: https:/ / www.sciencedirect.com/science/article/abs/pii/S0272638621007307 (accessed on 12 December 2021). [CrossRef]

89. Küllmar, M.; Weiß, R.; Ostermann, M.; Campos, S.; Grau Novellas, N.; Thomson, G.; Haffner, M.; Arndt, C.; Wulf, H.; Irqsusi, M.; et al. A Multinational Observational Study Exploring Adherence With the Kidney Disease: Improving Global Outcomes Recommendations for Prevention of Acute Kidney Injury After Cardiac Surgery. Anesth. Analg. 2020, 130, 910-916. [CrossRef]

90. Zarbock, A.; Küllmar, M.; Ostermann, M.; Lucchese, G.; Baig, K.; Cennamo, A.; Rajani, R.; McCorkell, S.; Arndt, C.; Wulf, H.; et al . Prevention of Cardiac Surgery-Associated Acute Kidney Injury by Implementing the KDIGO Guidelines in High-Risk Patients Identified by Biomarkers: The PrevAKI-Multicenter Randomized Controlled Trial. Anesth. Analg. 2021, 133, 292-302. [CrossRef]

91. Moledina, D.G.; Belliveau, O.; Yamamoto, Y.; Arora, T.; Carey, K.A.; Churpek, M.; Martin, M.; Partridge, C.M.; Mansour, S.G.; Parikh, C.R.; et al. Variation in Best Practice Measures in Patients With Severe Hospital-Acquired Acute Kidney Injury: A Multicenter Study. Am. J. Kidney Dis. 2021, 77, 547-549. [CrossRef] [PubMed]

92. Schaubroeck, H.A.I.; Vargas, D.; Vandenberghe, W.; Hoste, E.A.J. Impact of AKI care bundles on kidney and patient outcomes in hospitalized patients: A systematic review and meta-analysis. BMC Nephrol. 2021, 22, 335. [CrossRef] [PubMed]

93. Barry, R.; James, M.T. Guidelines for Classification of Acute Kidney Diseases and Disorders. Nephron 2015, 131, 221-226. [CrossRef] [PubMed]

94. Levey, A.S. Defining AKD: The Spectrum of AKI, AKD, and CKD. Nephron 2021, 1-4. [CrossRef] [PubMed]

95. See, E.J.; Polkinghorne, K.R.; Toussaint, N.D.; Bailey, M.; Johnson, D.W.; Bellomo, R. Epidemiology and Outcomes of Acute Kidney Diseases: A Comparative Analysis. Am. J. Nephrol 2021, 52, 342-350. [CrossRef]

96. Jordan, M.; Ortiz-Soriano, V.; Pruitt, A.; Chism, L.; Liu, L.J.; Chaaban, N.; Elias, M.; Sawaya, B.P.; Chen, J.; Neyra, J.A. Kidney Recovery in Patients With Acute Kidney Injury Treated in Outpatient Hemodialysis or Rehabilitation Facilities. Kidney Med. 2021, 3, 916-924.e911. [CrossRef]

97. Rathore, A.S.; Chopra, T.; Ma, J.Z.; Xin, W.; Abdel-Rahman, E.M. Long-Term Outcomes and Associated Risk Factors of PostHospitalization Dialysis-Dependent Acute Kidney Injury Patients. Nephron 2017, 137, 105-112. [CrossRef]

98. Lumlertgul, N.; Pirondini, L.; Cooney, E.; Kok, W.; Gregson, J.; Camporota, L.; Lane, K.; Leach, R.; Ostermann, M. Acute kidney injury prevalence, progression and long-term outcomes in critically ill patients with COVID-19: A cohort study. Ann. Intensive Care 2021, 11, 123. [CrossRef]

99. Alobaidi, R.; Anton, N.; Burkholder, S.; Garros, D.; Garcia Guerra, G.; Ulrich, E.H.; Bagshaw, S.M. Association Between Acute Kidney Injury Duration and Outcomes in Critically Ill Children. Pediatr. Crit. Care Med. 2021, 22, 642-650. [CrossRef]

100. Han, S.S.; Kim, S.; Ahn, S.Y.; Lee, J.; Kim, D.K.; Chin, H.J.; Chae, D.W.; Na, K.Y. Duration of acute kidney injury and mortality in critically ill patients: A retrospective observational study. BMC Nephrol. 2013, 14, 133. [CrossRef]

101. Federspiel, C.K.; Itenov, T.S.; Mehta, K.; Hsu, R.K.; Bestle, M.H.; Liu, K.D. Duration of acute kidney injury in critically ill patients. Ann. Intensive Care 2018, 8, 30. [CrossRef] [PubMed]

102. Brown, J.R.; Kramer, R.S.; Coca, S.G.; Parikh, C.R. Duration of acute kidney injury impacts long-term survival after cardiac surgery. Ann. Thorac. Surg. 2010, 90, 1142-1148. [CrossRef]

103. Coca, S.G.; King, J.T., Jr.; Rosenthal, R.A.; Perkal, M.F.; Parikh, C.R. The duration of postoperative acute kidney injury is an additional parameter predicting long-term survival in diabetic veterans. Kidney Int. 2010, 78, 926-933. [CrossRef]

104. Kellum, J.A.; Sileanu, F.E.; Bihorac, A.; Hoste, E.A.; Chawla, L.S. Recovery after Acute Kidney Injury. Am. J. Respir. Crit. Care Med. 2017, 195, 784-791. [CrossRef] [PubMed] 
105. Bellomo, R.; Ronco, C.; Mehta, R.L.; Asfar, P.; Boisramé-Helms, J.; Darmon, M.; Diehl, J.L.; Duranteau, J.; Hoste, E.A.J.; Olivier, J.B.; et al. Acute kidney injury in the ICU: From injury to recovery: Reports from the 5th Paris International Conference. Ann. Intensive Care 2017, 7, 49. [CrossRef] [PubMed]

106. Göcze, I.; Wiesner, C.; Schlitt, H.J.; Bergler, T. Renal recovery. Best Pract. Res. Clin. Anaesthesiol. 2017, 31, 403-414. [CrossRef]

107. Forni, L.G.; Darmon, M.; Ostermann, M.; Oudemans-van Straaten, H.M.; Pettilä, V.; Prowle, J.R.; Schetz, M.; Joannidis, M. Renal recovery after acute kidney injury. Intensive Care Med. 2017, 43, 855-866. [CrossRef]

108. Lee, B.J.; Hsu, C.Y.; Parikh, R.; McCulloch, C.E.; Tan, T.C.; Liu, K.D.; Hsu, R.K.; Pravoverov, L.; Zheng, S.; Go, A.S. Predicting Renal Recovery After Dialysis-Requiring Acute Kidney Injury. Kidney Int. Rep. 2019, 4, 571-581. [CrossRef]

109. Duff, S.; Murray, P.T. Defining Early Recovery of Acute Kidney Injury. Clin. J. Am. Soc. Nephrol. 2020, 15, 1358-1360. [CrossRef]

110. Kellum, J.A.; Romagnani, P.; Ashuntantang, G.; Ronco, C.; Zarbock, A.; Anders, H.J. Acute kidney injury. Nat. Rev. Dis. Primers 2021, 7, 52. [CrossRef]

111. Silver, S.A.; Harel, Z.; McArthur, E.; Nash, D.M.; Acedillo, R.; Kitchlu, A.; Garg, A.X.; Chertow, G.M.; Bell, C.M.; Wald, R. 30-Day Readmissions After an Acute Kidney Injury Hospitalization. Am. J. Med. 2017, 130, 163-172. [CrossRef]

112. Sawhney, S.; Marks, A.; Fluck, N.; McLernon, D.J.; Prescott, G.J.; Black, C. Acute kidney injury as an independent risk factor for unplanned 90-day hospital readmissions. BMC Nephrol. 2017, 18, 9. [CrossRef]

113. Vanmassenhove, J.; Vanholder, R.; Lameire, N. Points of Concern in Post Acute Kidney Injury Management. Nephron 2018, 138, 92-103. [CrossRef] 